\title{
The Roundness and Microstructure of Thin-wall Bearing Rings
}

Augustín Sládek, Peter Fabian, Richard Pastirčák, Martin Brezničan

Department of Technological Engineering, Faculty of Mechanical Engineering, University of Žilina, Univerzitná 1,010

26 Žilina, Slovakia. augustin.sladek@fstroj.uniza.sk

Heat treatment of rolling bearings components is an indispensable part of their production and also is the unavoidable item of the price in calculating of bearings. Technological process of heat treatment must be created rationally and in addition to the required hardness must also ensure the dimensional precision of bearings components. For predicting of the development of thermal and mechanical properties during heat treatment (for simulation only quenching) we used the simulation software SYSWELD from ESI Group. In addition to the microstructure and hardness the simulation results also consist of values of deformations and stresses in each axis $(X, Y, Z)$, which cause distortions during the heat treatment. The results can be used for the selection of material, editing of shape bearings with respect to heat treatment and proposal of the optimal technological process of heat treatment. The results were compared with real measured values of hardness, but especially with values of deformations in each axis.

Key words: bearing rings, simulation, SYSWELD, quenching, 100CrMnSi6-4

\section{References}

[1] BESWICK, J. (2002): Bearing Steel Technology, ASTM, West Conshohocken.

[2] DURAND-CHARRE, M. (2004). Microstructure of Steels and Cast Irons. Berlín: Springer-Verlag Berlin Heidelberg New York. 399 p. ISBN 978-3-540-20963-8

[3] HAKAN GÜR, C - PAN, J. (2008). Handbook of Thermal Process Modeling of Steels. pp. 342 - 380, Taylor \& Francis Group LLC, Boca Raton.

[4] KANG, S. H. - IM, Y. T. (2007). Thermo-elasto-plastic finite elements analysis of quenching process of carbon steel. Journal of Materials Processing Technology, No. 192 - 193, pp. 381 - 390.

[5] JERSÁK, J., et al. (2009). The Integrity of the Surface after Milling of Quenched Bearing Steel. Manufacturing Technology, No. 4. pp. 13 - 20. ISSN 1211-4162.

[6] MARTIENSSEN, W; WARLIMONT, H. (2005). Springer Handbook of Condensed Matter and Materials Data. Berlín: Springer-Verlag Berlin Heidelberg, New York. 1120 p. ISBN 978-3-540-44376-6.

[7] MORAVEC, J. (2009). Fusion welding simulation - simulation program SYSWELD. Welder, Vol. 6, No. 2, pp. $9-12$.

[8] PANDA, A. et al. (2011). Optimization of heat treatment bearing rings with goal to eliminate deformation of material. The Chemical Sheets, No. 16/2011, pp. $459-467$.

[9] PEREZ, M et al. (2009). Microstructural evolution of martensitic 100Cr6 bearing steel during tempering. Acta Materialia, Vol. 57, No. 11, pp. 3171-3180.

[10] TOTTEN, G. E.; BATES, C. E.; CLINTON, N. A. (1992). Handbook of Quenchants and Quenching Technology. ASM International.

[11] VANDER VOORT, G. F. (1991). Atlas of time-temperature diagrams for irons and steels. ASM International.

[12] VANDER VOORT, G. F. (2009). Martensite and Retained Austenite. Industrial Heating. 